\title{
Inventory of ascidians (Tunicata, Ascidiacea) from the National Park La Restinga, Isla Margarita, Venezuela
}

\author{
Rosana Moreira Rocha ${ }^{1,11}$, Edlin Guerra-Castro ${ }^{2}$,Carlos Lira ${ }^{3}$,Sheila Marquez Pauls ${ }^{4}$ Ivan Hernández,

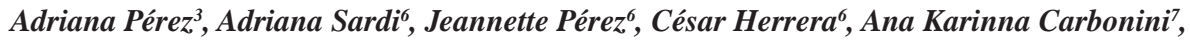 \\ Virginia Caraballo $^{3}$, Dioceline Salazar ${ }^{8}$, Maria Cristina Diaz ${ }^{9}$ \& Juan José Cruz-Motta ${ }^{6,10}$ \\ ${ }^{1}$ Departamento de Zoologia, Universidade Federal do Paraná - UFPR, \\ CP 19020, CEP 82531-980 Curitiba, PR, Brasil \\ ${ }^{2}$ Centro de Ecología, Instituto Venezolano de Investigaciones Científicas, \\ CP 21827, Caracas 1020-A, Venezuela, e-mail: eguerra@ivic.ve \\ ${ }^{3}$ Laboratorio de Zoología, Universidad de Oriente, Núcleo de Nueva Esparta, \\ Escuela de Ciencias Aplicadas del Mar, \\ CP 658, Porlamar 6301, Isla Margarita, Venezuela, e-mail: c_lira_g@hotmail.com, \\ adripeva@gmail.com,amanonvi@gmail.com \\ ${ }^{4}$ Instituto de Zoologia Tropical, Escuela de Biologia, Universidad Central de Venezuela, \\ CP 47058, Caracas 1041,Venezuela, e-mail: s.m.pauls@gmail.com \\ ${ }^{5}$ Departamento de Ciencias, Universidad de Oriente, Núcleo de Nueva Esparta, \\ Guatamara, Isla de Margarita, Venezuela, e-mail: ivanhernavila@yahoo.com \\ ${ }^{6}$ Laboratorio de Ecología Experimental, Universidad Simón Bolívar, \\ CP 89000, Sartenejas, Caracas 1080, Venezuela, \\ e-mail: adrianasardi@gmail.com, jeannetteperezbenitez@yahoo.es, herrera.ce@gmail.com \\ ${ }^{7}$ Laboratorio de Biología Marina, Universidad Simón Bolívar, \\ CP 89000, Sartenejas, Caracas 1080,Venezuela, e-mail: carbonini@usb.ve \\ ${ }^{8}$ Departamento de Biología, Escuela de Ciencias, Universidad de Oriente, Núcleo de Sucre, \\ CP 245, CEP 6101,Cumaná, Venezuela, e-mail: disalma21@gmail.com \\ ${ }^{9}$ Museo Marino de Margarita, Bulevar El Paseo, \\ Boca del Río, Margarita, Edo. Nueva Esparta, Venezuela, e-mail: taxochica@gmail.com \\ ${ }^{10}$ Departamento de Estudios Ambientales, Universidad Simón Bolívar, \\ CP 89000, Sartenejas, Caracas 1080,Venezuela, e-mail: juancruz@usb.ve \\ ${ }^{11}$ Corresponding author: Rosana Moreira Rocha, e-mail: rmrocha@ufpr.br
}

ROCHA, R.M., GUERRA-CASTRO, E., LIRA, C., PAUL, S.M., HERNÁNDEZ. I., PÉREZ, A., SARDI, A., PÉREZ. J., HERRERA, C., CARBONINI, A.K., CARABALlO, V., SALAZAR, D., DIAZ, M.C. \& CRUZMOTTA, J.J. Inventory of ascidians (Tunicata, Ascidiacea) from the National Park La Restinga, Isla Margarita, Venezuela. Biota Neotrop. 10(1): http://www.biotaneotropica.org.br/v10n1/en/abstract?inventory +bn00510012010.

\begin{abstract}
Although ascidians form a conspicuous part of sessile assemblages in the Caribbean, no specialized inventories have been developed in Venezuela, except for a list of 15 species reported from Margarita Island (1984). Here we present the results of a taxonomic workshop held in the Universidad de Oriente, Boca del Rio, Margarita Island during April 20-25 of 2009, sponsored by the NaGISA-Caribbean Sea program. La Restinga National park was surveyed and we found 29 species belonging to 19 genera and 10 families. The most abundant colonial species were Clavelina oblonga, Aplidium accarense, Polyclinum constellatum, Distaplia bermudensis, Symplegma rubra, S. brakenhielmi, Botrylloides nigrum and Ecteinascidia turbinata. Among the solitary ascidians Phallusia nigra, Ascidia curvata, Microcosmus exasperatus, Styela canopus, Styela sp.1 and Styela sp. 2 were the most abundant. The ascidian diversity in this lagoon is one of the highest for similar habitats in the Caribbean and seven species are new registers for Venezuela (Ascidia curvata, Ecteinascidia styeloides, Aplidium accarense, Distaplia stylifera, Trididemnum orbiculatum, Symplegma rubra, and S. brakenhielmi). One point of concern for the conservation of la Restinga National Park is the presence of possible introduced species, and some management procedures are suggested.
\end{abstract}

Keywords: Urochordata, taxonomy, South Caribbean, mangrove, coastal lagoon, conservation, bioinvasion. 
ROCHA, R.M., GUERRA-CASTRO, E., LIRA, C., PAUL, S.M., HERNÁNDEZ. I., PÉREZ, A., SARDI, A., PÉREZ. J., HERRERA, C., CARBONINI, A.K., CARABALLO, V., SALAZAR, D., DIAZ, M.C. \& CRUZ- MOTTA, J.J. Inventário de ascídias (Tunicata, Ascidiacea) do Parque Nacional La Restinga, Isla Margarita, Venezuela. Biota Neotrop. 10(1): http://www.biotaneotropica.org.br/v10n1/pt/abstract?inventory+bn00510012010.

Resumo: Apesar das ascídias formarem uma parte conspícua das comunidades incrustantes no Caribe, nenhum inventário especializado foi realizado na Venezuela, com exceção de uma lista de 15 espécies registradas na Ilha Margarita (1984). Aqui apresentamos os resultados de um workshop de taxonomia realizado na Universidad de Oriente, Boca del Rio, Margarita Island em 20-25 de abril de 2009, como parte do programa NaGISA-Caribbean Sea program. O Parque Nacional La Restinga foi estudado e encontradas 29 espécies pertencendo a 19 gêneros e 10 famílias. As espécies coloniais mais abundantes foram Clavelina oblonga, Aplidium accarense, Polyclinum constellatum, Distaplia bermudensis, Symplegma rubra, S. brakenhielmi, Botrylloides nigrum e Ecteinascidia turbinata. Entre as espécies solitárias, Phallusia nigra, Ascidia curvata, Microcosmus exasperatus, Styela canopus, Styela sp.1 e Styela sp. 2 foram as mais abundantes. A diversidade de ascídias nesta laguna é uma das maiores neste tipo de habitat no Caribe e sete espécies representam novos registros para a Venezuela (Ascidia curvata, Ecteinascidia styeloides, Aplidium accarense, Distaplia stylifera, Trididemnum orbiculatum, Symplegma rubra, e S. brakenhielmi). Uma questão de preocupação para a conservação do Parque Nacional La Restinga é a presença de possíveis espécies exóticas, portanto algumas medidas de manejo são sugeridas.

Palavras-chave: Urochordata, taxonomia, Caribe Sul, manguezal, laguna costeira, conservação, bioinvasão.

\section{Introduction}

Ascidians are one of the most conspicuous invertebrate groups in coastal benthic assemblages. In the Caribbean, inventories of ascidian species have been done at Netherlands Antilles (Millar 1962, Goodbody 1984a), Guadeloupe (Monniot, C. 1983a, b, c \& Monniot, F. 1983a, b, c), Jamaica (Goodbody 1993, 2003), Cuba (Zanui 1990), Belize (Goodbody 2000, 2004) and Panama (Rocha et al. 2005). In Venezuela, however, no specialized inventories have been developed except for the list of 15 species presented by Goodbody (1984b) for Margarita Island. In general, reports of ascidians from the Venezuelan Coast come mainly from ecological studies such as Sutherland (1980), Montes (1985), Álvarez (1989) and Orihuela et al. (1991) and the status of endemic, regional or even invasive ascidians in Venezuela is completely unknown (Zoppi de Roa 2003). This situation has prevented detailed descriptions of macrobenthic assemblages such as those growing on mangrove roots, coral reefs, rocky shores and Thalassia beds (Conde \& Carmona-Suárez 2003, Miloslavich et al. 2005).

The survey reported here was done in the National Park La Restinga where diverse and abundant assemblages of tunicates grow on the mangrove roots (Cervigon \& Gomez 1986, Orihuela et al. 1991, Díaz et al. 1992). La Restinga has been preserved as a national park since 1974 because of its highly diverse habitat contrasting with the arid vegetation of the terrestrial environment surrounding it (Presidential Ordinance $n^{\circ} 1591$ ). This important system attracted the interest of many scientists whose studies included ecological aspects of primary production and planktonic biomass (Gómez 1983), polychaetes (Díaz \& Liñero 2009), mollusks (González 1976, Nirchio et al. 1991, Bigatti et al. 2005, Miloslavich et al. 2007, Buitrago et al. 2009), crustaceans (Scelzo 1972, López Greco et al. 2001, Bolaños et al. 2004), fishes (Gómez 1981, Fuentes et al. 2003, Marín et al. 2003), and mangrove root fouling (Orihuela et al. 1991). However, a few studies described the ascidian fauna and only 15 species have been reported (Goodbody 1984b, Orihuela et al. 1991), representing a very small diversity for a Caribbean lagoon bordered by mangrove habitat. Although a few lagoons have been studied in the Caribbean, those better known usually contain between 25-40 species of ascidians (Toffart 1983, Goodbody 2004). Our survey increased the registers of ascidians in the mangrove complex La Restinga to at least 29 species.

\section{Material and Methods}

\section{Study site}

La Restinga is a coastal hypersaline lagoon located in the central part of Margarita Island, Venezuela. The lagoon has an area of $30 \mathrm{~km}^{2}$, maximum depth of $6 \mathrm{~m}$ and is formed by a complex system of channels and ponds bordered by mangrove habitats. Detailed description of the environmental characteristics of the lagoon is provided by Cabrera \& Penoth (1988), Gómez (1991), Orihuela et al. (1991), Ramírez (1996) and Salazar et al. (2003).

In general, the ascidians attach to the mangrove prop roots of Rhizophora mangle, usually in large biomass, and represent an important portion of the fouling community (Sutherland 1980, Álvarez 1989, Díaz et al. 1992, Farnsworth \& Ellison 1996, Goodbody 2000).

This survey was performed in four sites inside La Restinga: Entrance, Mánamo, La Tortuga and La Isleta (Figure 1). The Entrance

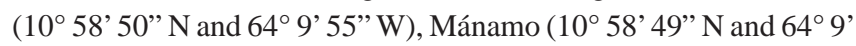
$\left.22^{\prime} \mathrm{W}\right)$ and La Isleta ( $10^{\circ} 59^{\prime} 13^{\prime}$ ' $\mathrm{N}$ and $\left.64^{\circ} 09^{\prime} 17^{\prime} \mathrm{W}\right)$ have a stable salinity around 36-38\% and strong tidal currents (Gómez 1991). La Tortuga ( $11^{\circ} 00^{\prime} 07^{\prime \prime} \mathrm{N}$ and $\left.64^{\circ} 09^{\prime} 47^{\prime \prime} \mathrm{W}\right)$ is a hypersaline area, presenting salinity up to $45 \%$ (Gómez 1991). The movement of fishing

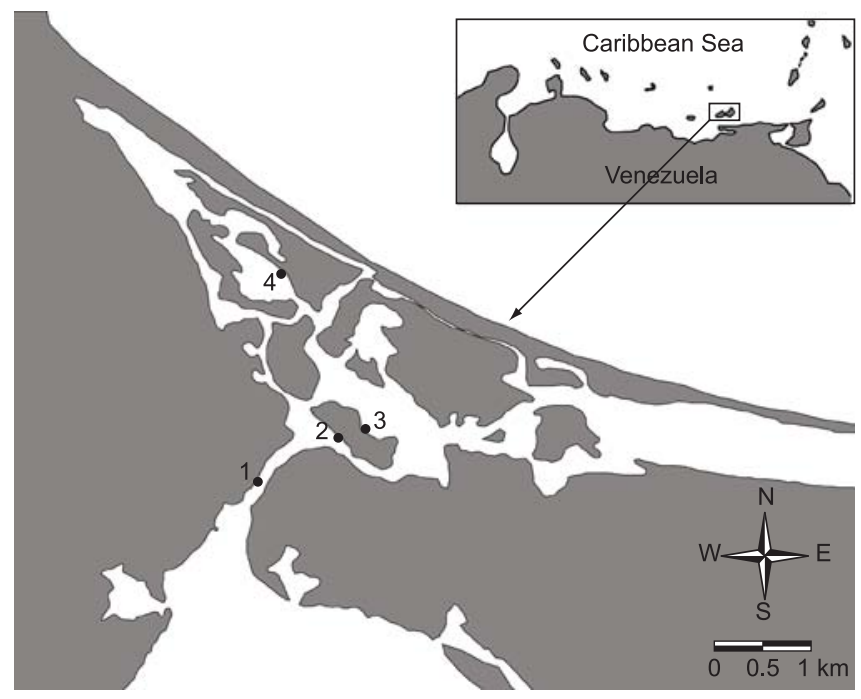

Figure 1. Map of la laguna of La Restinga National Park, Margarita Island, Venezuela. 1 - Entrance, 2 - Mánamo, 3 - La Isleta , 4 - La Tortuga. Insert showing location of Magarita Island. 
and leisure boats is intense, increasing both the water hydrodynamics and the potential for species transport.

\section{Field and laboratory work}

The survey was performed on $20^{\text {th }}$ and $21^{\text {st }}$ of April 2009, with an effort of 1 hour snorkeling in each site by 14 divers. Specimens were photographed before collection for color and shape assessment of living animals. Samples were relaxed for 2 hours in a menthol-saturated sea-water solution and fixed in 5\% seawater formalin.

Dissection followed routine methods (Monniot, C \& Monniot, F 1972) and the literature for Caribbean ascidians and adjacent regions was consulted for identification (Berrill 1932, Van Name 1945, Millar 1962, 1978, Van der Sloot 1969, Monniot, C. 1972a, b, 1983a, b, c, Monniot,
F. 1972, 1983a, b, c, Millar \& Goodbody 1974, Monniot, C \& Monniot, F 1984, Goodbody 1984a, 1984b, 1993, 1994, 2000, 2003, 2004, Goodbody \& Cole 1987, 2006, Zanui 1990, Rocha et al. 2005).

Voucher specimens of all sampled species are deposited in the reference collections of the Museo Marino de Margarita, Isla Margarita and Museo Oceanológico "Benigno Roman" de la Estación de Investigaciones Marinas de Margarita (EDIMAR) - Fundación La Salle de Ciencias Naturales.

\section{Results}

We found 29 species belonging to 19 genera and 10 families (Table 1). Colonial species were abundant, usually covering soli-

Table 1. List of the species found at La Restinga National Park, Boca del Río, Isla Margarita, Venezuela. The number of Xs correspond to the relative visual abundance of the species comparing the four sites.

\begin{tabular}{|c|c|c|c|c|}
\hline & Mánamo & La Tortuga & Entrance & La Isleta \\
\hline \multicolumn{5}{|l|}{ Corellidae } \\
\hline Rhodosoma turcicum (Savigny, 1816) & - & - & $\mathrm{XX}$ & - \\
\hline \multicolumn{5}{|l|}{ Ascidiidae } \\
\hline Phallusia nigra Savigny, 1816 & $\mathrm{XXX}$ & $\mathrm{X}$ & XXX & $\mathrm{XX}$ \\
\hline Ascidia curvata (Traustedt, 1882) & $\mathrm{XX}$ & - & XX & $\mathrm{X}$ \\
\hline Ascidia sp. & $\mathrm{X}$ & $\mathrm{X}$ & $\mathrm{X}$ & $\mathrm{X}$ \\
\hline \multicolumn{5}{|l|}{ Perophoridae } \\
\hline Ecteinascidia styeloides (Traustedt, 1882) & - & - & $\mathrm{X}$ & $\mathrm{X}$ \\
\hline Ecteinascidia turbinata Herdman, 1880 & XXX & $\mathrm{X}$ & $\mathrm{XXX}$ & $\mathrm{XX}$ \\
\hline Perophora viridis Verrill, 1871 & - & - & $\mathrm{X}$ & - \\
\hline \multicolumn{5}{|l|}{ Clavelinidae } \\
\hline Clavelina oblonga Herdman, 1880 & $\mathrm{XXX}$ & $\mathrm{X}$ & $\mathrm{XXX}$ & $\mathrm{XXX}$ \\
\hline \multicolumn{5}{|l|}{ Polyclinidae } \\
\hline Aplidium accarense (Millar, 1953) & $\mathrm{XXX}$ & $\mathrm{X}$ & $\mathrm{XXX}$ & $\mathrm{XX}$ \\
\hline Polyclinum constellatum Savigny, 1816 & $\mathrm{X}$ & XXX & $\mathrm{X}$ & $\mathrm{X}$ \\
\hline \multicolumn{5}{|l|}{ Holozoidae } \\
\hline Distaplia bermudensis Van Name, 1902 & $\mathrm{XX}$ & - & XXX & $\mathrm{X}$ \\
\hline Distaplia stylifera (Kowalevsky, 1874) & - & - & $\mathrm{XX}$ & $\mathrm{X}$ \\
\hline \multicolumn{5}{|l|}{ Didemnidae } \\
\hline Diplosoma listerianum (Milne-Edwards, 1841) & $\mathrm{X}$ & $\mathrm{XX}$ & $\mathrm{X}$ & $\mathrm{X}$ \\
\hline Lissoclinum fragile (Van Name, 1902) & $\mathrm{XX}$ & - & $\mathrm{X}$ & $\mathrm{X}$ \\
\hline Lissoclinum sp. & $\mathrm{X}$ & - & $\mathrm{X}$ & $\mathrm{X}$ \\
\hline Didemnum cineraceum (Sluiter, 1898) & - & - & $\mathrm{X}$ & - \\
\hline Didemnum duplicatum Monniot, 1983 & $\mathrm{X}$ & - & - & - \\
\hline Didemnum perlucidum Monniot, 1983 & - & - & $\mathrm{XX}$ & $\mathrm{X}$ \\
\hline Trididemnum orbiculatum (Van Name, 1902) & $\mathrm{X}$ & - & $\mathrm{X}$ & - \\
\hline \multicolumn{5}{|l|}{ Styelidae } \\
\hline Symplegma brakenhielmi (Michaelsen, 1904) & XXX & $\mathrm{X}$ & $\mathrm{XXX}$ & $\mathrm{XXX}$ \\
\hline Symplegma rubra Monniot, 1972 & $\mathrm{XXX}$ & - & $\mathrm{XXX}$ & $\mathrm{X}$ \\
\hline Botrylloides nigrum (Herdman, 1886) & XXX & $\mathrm{XX}$ & $\mathrm{XXX}$ & $\mathrm{XXX}$ \\
\hline Botrylloides sp. & XXX & $\mathrm{X}$ & $\mathrm{X}$ & $\mathrm{X}$ \\
\hline Styela canopus Savigny, 1816 & $\mathrm{X}$ & $\mathrm{X}$ & $\mathrm{XXX}$ & $\mathrm{XX}$ \\
\hline Styela sp. 1 & XXX & $\mathrm{XX}$ & $\mathrm{XXX}$ & $\mathrm{XXX}$ \\
\hline Styela sp. 2 & $\mathrm{XX}$ & $\mathrm{X}$ & X & $\mathrm{XX}$ \\
\hline \multicolumn{5}{|l|}{ Pyuridae } \\
\hline Microcosmus exasperatus Heller, 1878 & XXX & $\mathrm{XX}$ & XXX & XXX \\
\hline Herdmania pallida (Heller, 1878) & - & - & $X$ & - \\
\hline \multicolumn{5}{|l|}{ Molgulidae } \\
\hline Molgula occidentalis Traustedt, 1883 & $\mathrm{X}$ & - & $\mathrm{X}$ & - \\
\hline TOTAL & 22 & 14 & 28 & 22 \\
\hline
\end{tabular}


Rocha, R.M. et al.
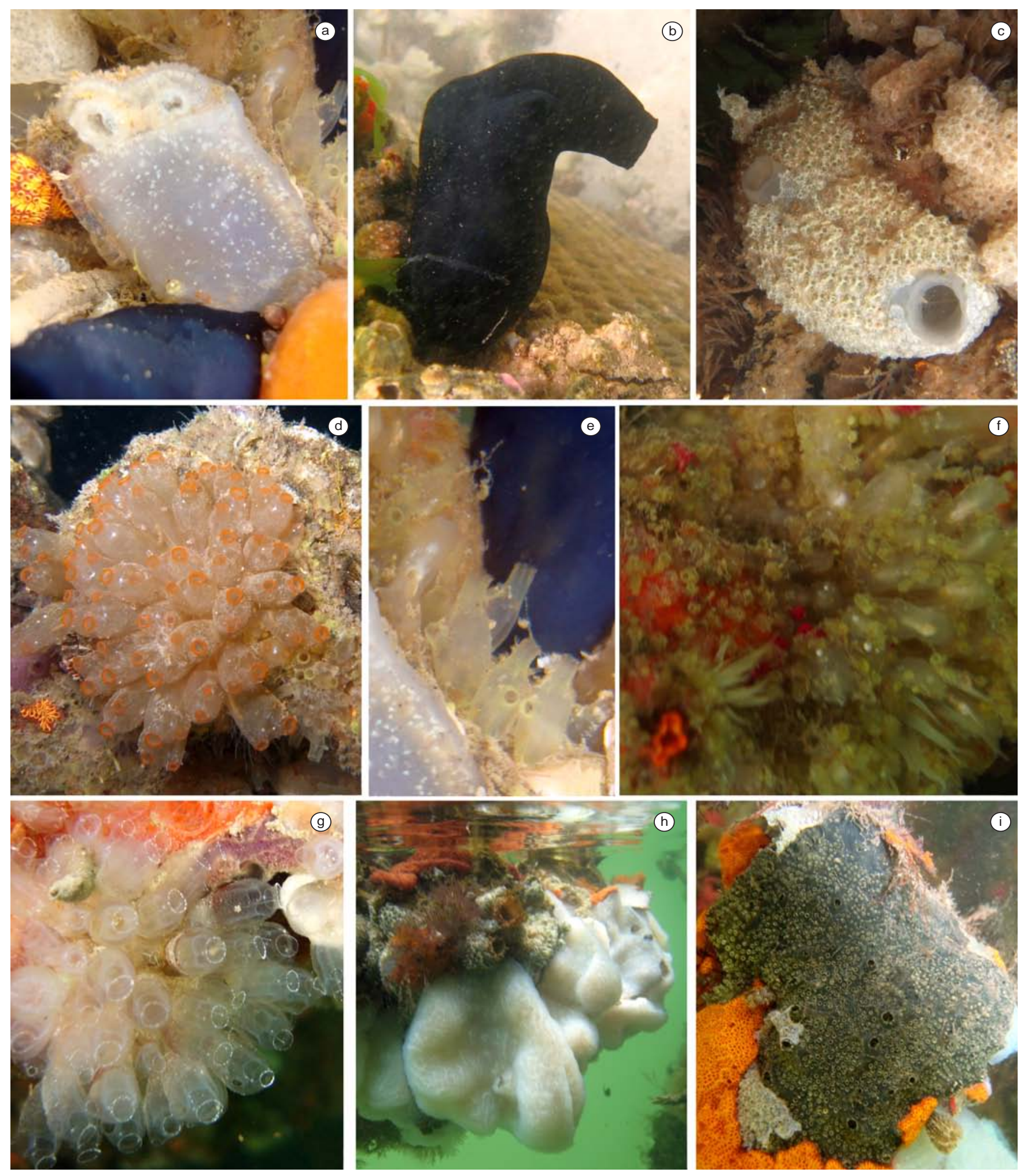

Figure 2. a) Rhodosoma turcicum (Savigny, 1816); b) Phallusia nigra Savigny, 1816; c) Ascidia curvata (Traustedt, 1882) covered by Symplegma brakenhielmi; d) Ecteinascidia turbinata Herdman, 1880; e) Ecteinascidia styeloides (Traustedt, 1882); f) Perophora viridis Verrill, 1871; g) Clavelina oblonga Herdman, 1880; h) Aplidium accarense (Millar, 1953); i) Polyclinum constellatum Savigny, 1816. Photos credits: a, e, f, g) RMR; b) AKC; c,d) CH; h. SMP; i) EGC. 

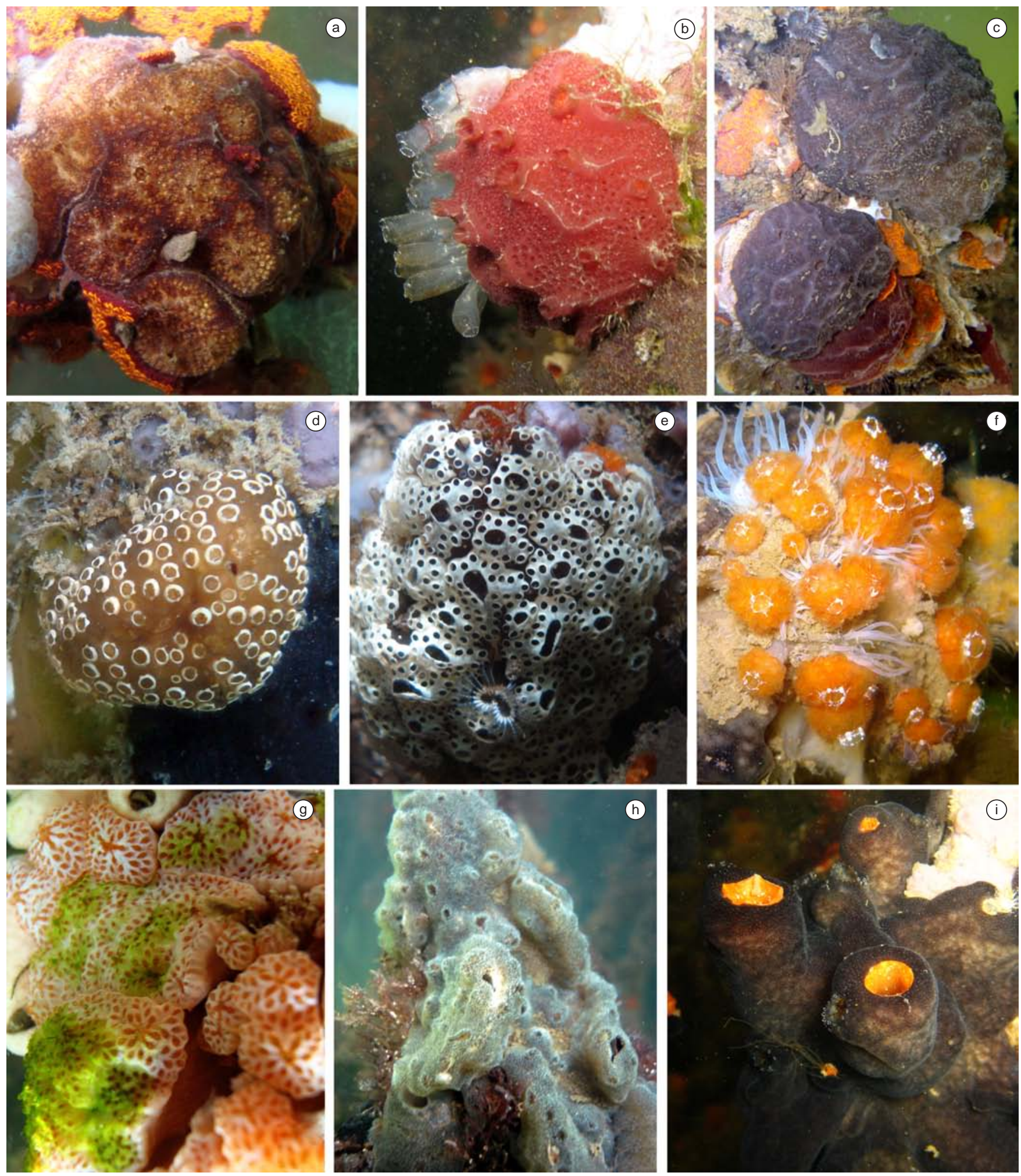

Figure 3. a, b, c) Polyclinum constellatum Savigny, 1816; d, e) Distaplia bermudensis Van Name, 1902; f, g) Distaplia stylifera (Kowalevsky, 1874); h) Diplosoma listerianum (Milne-Edwards, 1841); i) Didemnum cineraceum (Sluiter, 1898). Photos credits: a, d) EGC; b) SMP; c) RMR; e, f) AP; g) JP; h) MCD; i)AKC. 
Rocha, R.M. et al.
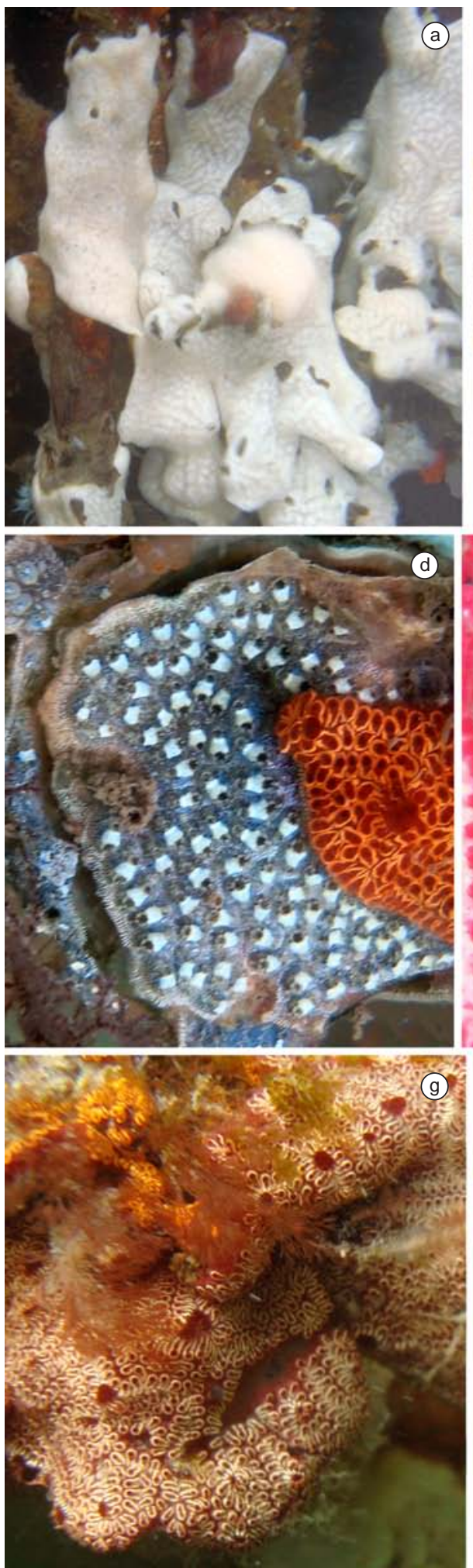
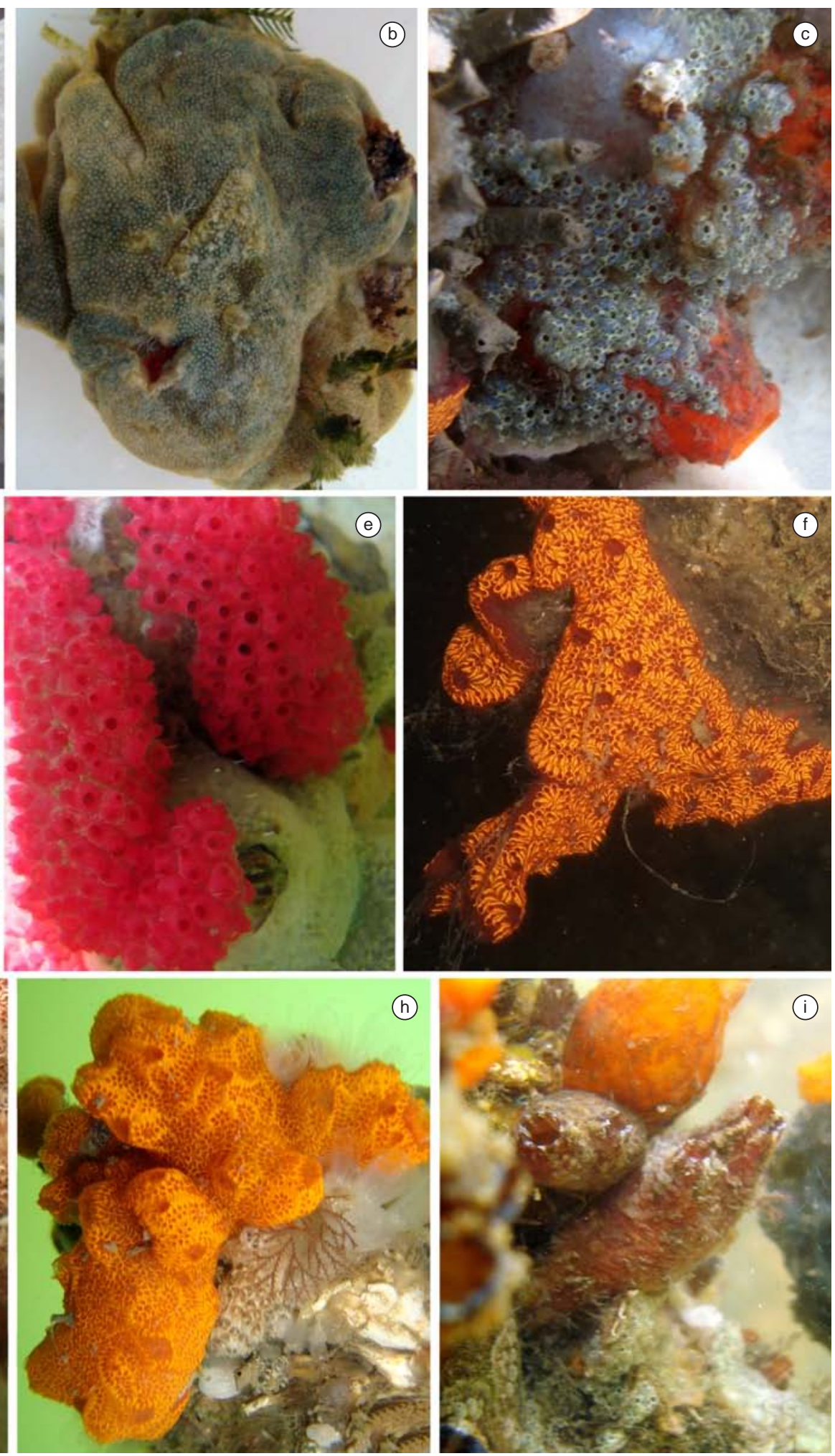

Figure 4. a) Didemnum perlucidum Monniot, 1983; b) Trididemnum orbiculatum (Van Name, 1902); c,d) Symplegma brakenhielmi (Michaelsen, 1904); e) Symplegma rubra Monniot, 1972; f, g) Botrylloides nigrum (Herdman, 1886); h) Botrylloides sp.; i) Styela canopus Savigny, 1816. Photos credits: a, b, i) RMR; c) SMP; d, e, h) EGC; f) CH. 

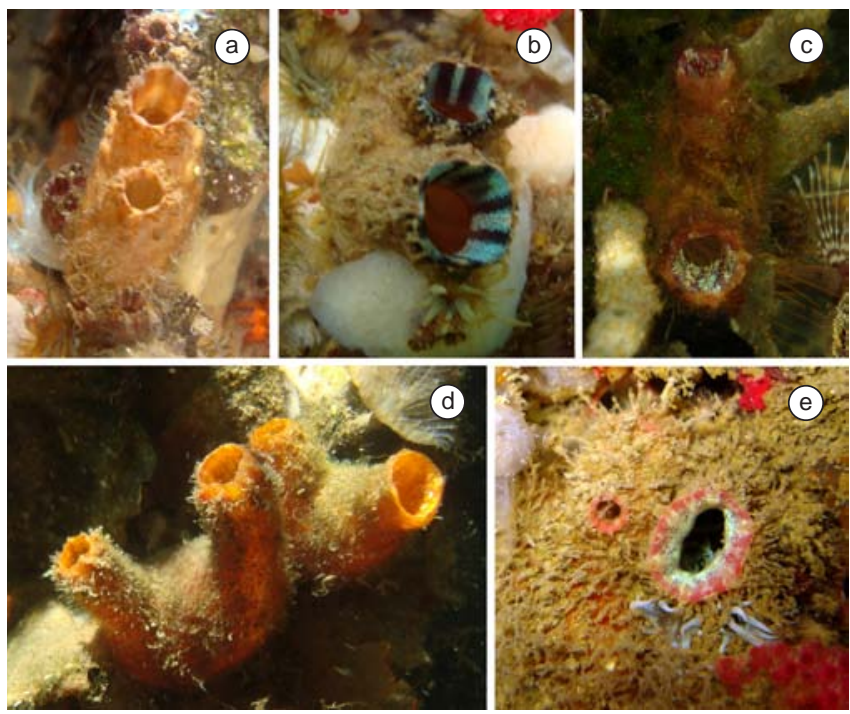

Figure 5. a) Styela sp. 2; b) Styela sp. 1; c) Herdmania pallida (Heller, 1878); d) Microcosmus exasperatus Heller, 1878; e) Molgula occidentalis Traustedt, 1883. Photos credits: a, b, c) RMR; d) EGC; e) AP.

tary animals. The most abundant species were Clavelina oblonga, Aplidium accarense, Polyclinum constellatum, Distaplia bermudensis, Symplegma rubra, S. brakenhielmi, Botrylloides nigrum and Ecteinascidia turbinata. Among the solitary ascidians Phallusia nigra, Ascidia curvata, Microcosmus exasperatus, Styela canopus, Styela sp.1 and Styela sp. 2 were the most abundant.

Five species were not identified either because of the lack of enough taxonomic characters or because they did not match with any Atlantic species: Ascidia sp., Lissoclinum sp., Botrylloides sp., Styela sp. 1 and Styela sp. 2. Ascidia sp. is very similar to Ascidia curvata but with red or orange vessels in the tunic, easily seen around the siphons. Lissoclinum sp. is white in the field but turns brown or orange in formalin. The colony contains a thin layer of more or less dense spicules (sometimes almost none) on the surface and the preserved zooids are very opaque with brown pigment and orange stigmata. The tunic is soft and extensively adheres to the zooids, at least in freshly fixed animals, which made it very difficult to pull out zooids in good condition for identification. Reproductive structures were not available for examination. Larvae present three adhesive papillae and four pairs of finger-like ampullae. Botrylloides sp. (Figure $4 \mathrm{~h}$ ) presents a uniform orange colony with long linear systems. Neither gonads or larvae were available for identification. Styela sp. 1 and Styela. sp. 2 present very similar internal structure but are considered separate species because of the different appearance of living animals. Styela sp. 1 has a white tunic and wide oral siphons; both siphons have wide radial blue bands inside (Figure 5b). In Styela sp. 2 the tunic is a light brown or rose, without the blue bands on the siphons but with many irregular tunic projections around both siphons (Figure 5a). In both species the body is elongate with a variable number of gonads in each side: Styela sp. 1 has 3-8 (right side) and 2-5 (left side); Styela sp. 2 has 5-7 (right side) (one specimen had no gonads on the right side), and 4-6 (left side). The structure of the gonads is also very similar with long tubular ovaries surrounded by orange elongate male follicles, not very dense or ramified, positioned vertically with only the proximal end attached to the body wall. The follicles of Styela sp. 1 were usually shorter than the ones in Styela sp. 2.

The Entrance was the most diverse site with 28 species, and La Tortuga was the least rich with 14 species (Table 1). The list of sampled species with a visual estimate of abundance is presented in Table 1 and photos of the species in the field are presented in Figures 2-5.

\section{Discussion}

Although the survey presented here was short and covered only four sites in the lagoon, we sampled 29 species of ascidians, a relatively high richness when compared to other Caribbean lagoons with mangrove habitats: 25 in Guadeloupe (Toffart 1983), 30 in Puerto Rico (Toffart 1983), 11 in Trinidad (Toffart 1983), 7 in Florida (Toffart 1983), 23 in Piscadera Baai, Curaçao (Goodbody 1984b), 15 in Lac, Bonaire (Goodbody 1984b), 55 in Pelican Cays, Belize (Goodbody 2000), 40 in Twin Cays, Belize (Goodbody 2004), 39 in Port Royal, Jamaica (Goodbody 2003), 29 in Almirante Bay, Bocas del Toro, Panama (Rocha et al. 2005).

Two previous studies reported 15 species for La Restinga (Goodbody 1984b, Orihuela et al. 1991) (Table 2). Among the species reported by Goodbody (1984b) and Orihuela et al. (1991), we did not encounter Ascidia interrupta, Didemnum conchyliatum, Symplegma viride and Styela plicata. The first two are common Caribbean species and new surveys can reveal their presence in the area. Symplegma viride could be easily confounded with $S$. brakenhielmi since differences between these species are subtle (see Monniot 1972b, 1983b for descriptions). Styela plicata is an introduced species in the Atlantic (Barros et al. 2009) found usually in high densities in harbors and marinas. Since we surveyed the same site mentioned by Goodbody (1984b) - "Puente de la Restinga" (= Entrance) and did not find any individuals, either the species has disappeared from the area or it was misidentified and perhaps was our Styela sp. 1 or Styela sp. 2.

Considering the list of known species for Venezuela, 30 species have been previously reported (Table 2). Ascidia curvata, Ecteinascidia styeloides, Aplidium accarense, Distaplia stylifera, Trididemnum orbiculatum, Symplegma rubra, and S. brakenhielmi are new records for this country but all species are widespread in the Caribbean. Aplidium accarense, though, was first described for Ghana, Africa (Millar 1953) and is also known from south Brazil where it is suspected to be introduced (Rocha et al. 2009). Molecular data would be helpful to better understand the genetic structure between the populations of A. accarense in the American and African Coasts. Distaplia stylifera is considered by Van Name (1945) as a synonymy of $D$. bursata. Both are very similar indeed because the description of $D$. bursata fits in the wide range of character variation reported for $D$. stylifera, for which the majority of records of are in the Indo-Pacific. In the Caribbean it was reported from the west coast of Florida, Jamaica and Colombia (Van Name 1945), but recent studies did not list the species in Jamaica (Goodbody 1993, 2003), Guadeloupe (Monniot, F 1983c) or Belize (Goodbody 2000, 2004). In Bocas del Toro, Panama, it occurs in the marina of the city, but only on artificial substrata (RMR, unpublished data). All this evidence also suggests that D. stylifera is not native in the Caribbean.

The Entrance was the richest site in species. Among the sampled species, only Didemnum duplicatum was not registered in The Entrance, but many white didemnids were observed but not collected because this was the last site visited and we were trying to not re-collect similar organisms. White didemnids, though, can not be certainly identified by pictures and it is possible that we will find not only D. duplicatum but other species in this site. Tidal currents in The Entrance may prevent sedimentation on the sessile community, usually a negative factor that causes mortality to recruits and juveniles (Young \& Chia 1984) and disturbs water filtration by the adults (Petersen 2007). At La Tortuga the high salinity seems to be strongly selecting against the survival of some species and only half of the species encountered during this study was registered at La Tortuga. Polyclinum constellatum was especially abundant at this site as ball-shaped colonies filled with a gelatinous tunic with the 
Table 2. List of known species for Venezuela.

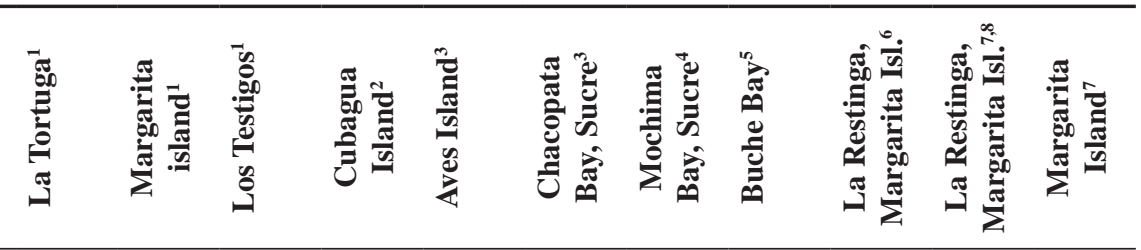

Diazonidae

Rhopalaea abdominalis (Sluiter, 1898)

Corellidae

Rhodosoma turcicum (Savigny, 1816)

Ascidiidae

Ascidia interrupta Heller, 1878

Phallusia nigra Savigny, 1816

Perophoridae

Ecteinascidia conklini Berrill, 1932

Ecteinascidia turbinata Herdman, 1880

Perophora bermudensis Berrill, 1932

Clavelinidae

Clavelina oblonga Herdman, 1880

Polyclinidae

Aplidium bermudae (Van Name, 1902)

Aplidium funginum (Sluiter, 1898)

Polyclinum constellatum Savigny, 1816

Polycitoridae

Eudistoma hepaticum (Van Name, 1921)

Eudistoma olivaceum (Van Name, 1902)

Holozoidae

Distaplia bermudensis Van Name, 1902

Didemnidae

Didemnum conchyliatum (Sluiter, 1898)

Didemnum duplicatum Monniot, 1983

Didemnum vanderhorsti Van Name, 1924

Diplosoma listerianum (Milne-Edwards, 1841)

Styelidae

Botrylloides nigrum (Herdman, 1886)

Symplegma viride Herdman, 1886

Styela canopus Savigny, 1816

Styela plicata (Lesueur, 1823)

Polycarpa appropinquata (Sluiter, 1898):

Polycarpa aurita (Sluiter, 1890)

Polycarpa nivosa (Sluiter, 1898)

Polycarpa spongiabilis (Traustedt, 1883)

\section{X}

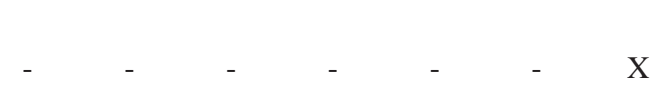

yuridae

Microcosmus exasperatus Heller, 1878

Herdmania pallida (Heller, 1878)

Pyura vittata (Stimpson, 1852)

Molgulidae

Molgula occidentalis Traustedt, 1883

${ }^{1}$ Sluiter 1898, ${ }^{2}$ Van Name $1945,{ }^{3}$ Millar 1962, ${ }^{4}$ Bermúdez \& Jimenez 1975, ${ }^{5}$ Sutherland 1980, ${ }^{6}$ Ramirez, 1996 (based in Galan 1976), ${ }^{7}$ Goodbody 1984b,

${ }^{8}$ Orihuela et al. 1991. 
zooids located only around the outer edge like the ones observed in Port Royal, Jamaica (Goodbody 2003).

One point of concern for the conservation of la Restinga National Park is the presence of possible introduced species, since it is a protected area (Presidential Ordinance $n^{\circ} 1591$ ). Other studies identified the presence of introduced species in Venezuela (Montes \& Prieto 2005, Perez et al. 2007) but the lack of comprehensive surveys allowed the recognition of only one introduced tunicate, Styela clava (Herdman, 1881). Given the fact that it is a cold water species, its identification is doubtful. Ascidians have been recognized as frequent invaders of new areas in recent years (Lambert 2005, 2007) causing major fouling problems for the bivalve aquaculture industry (Carver et al. 2003, LeBlanc et al. 2007). In natural environments they have the potential to displace native species causing reduction of biodiversity. In La Restinga we detected some species that are already widespread in the Caribbean and probably represent historical introductions such as Microcosmus exasperatus and Styela canopus. The presence of Ascidia sydneiensis was only guessed by photos and should be confirmed as well as Styela plicata. If present, these species are still not abundant and manual eradication could be tried. If Aplidium accarense and Distaplia stylifera prove to be introduced they represent a real threat to the diversity of the region, since they grow in large, massive colonies that could smother and displace other species.

The movement of recreational and fishing boats has already been shown to be an important vector for intraregional spread of invaders both in freshwater and marine environments (Johnson et al. 2001, Wasson et al. 2001, Darbyson et al. 2009). Frequent cleaning of the hulls and anchors, and control of water discharge, oyster shells and other shellfish refuse, are important management procedures toward the prevention of species dispersal. Furthermore, artificial substrates are also known as important habitats used by introduced species for first establishment (Glasby et al. 2007). The avoidance of construction of piers or other structures inside the lagoon which would add artificial substrate for colonization of sessile animals and frequent (less than two months) cleaning of existing structures are other prevention measures that should be followed. Managers should also promote periodic monitoring to increase the chances of early detection and possible eradication of introduced species.

Old photos of mangrove roots by CL and AP (2007-2008) showed the presence of a few species not collected in this survey, including Clavelina picta, Ascidia sydneiensis and a colony with round systems which resembles Distaplia corolla. Other cryptic species such as Corella minuta, Perophora spp. and Ecteinascidia minuta frequently found in Caribbean mangrove habitats are also expected in further collections in the area. It is also important to consider that the only two studied Caribbean lagoons that presented a richer community of ascidians than "La Restinga" are those in Belize that were studied for years and include temporary and rare species (Goodbody 2000, 2004). Thus the list here presented is far from complete and we expect to have 35-38 ascidian species in La Restinga lagoon, which would make this mangrove system among the ones with the highest biodiversity in the Caribbean.

\section{Acknowledgements}

This workshop was mainly sponsored by NaGISA-Caribbean Sea program. Special thanks to Prof. Juan Bolaños, Prof. Monzerrat Esteves and Prof. Jesús Rosas, all from Escuela de Ciencias Aplicadas del Mar, Universidad de Oriente, for logistic facilities in Boca del Rio. Special thanks to Prof. Jesús Eloy Conde from Center for Ecology, IVIC, for supporting this workshop with minor costs and lab material. We also extend our gratitude to Lic. Oscar Hernández from Instituto Nacional de Parques (INPARQUES). RMR received a research grant from $\mathrm{CNPq}$ and thanks the Bocas Research Marine Station - STRI for lab space while preparing this paper.

\section{References}

ÁLVAREZ, A. 1989. Establecimiento, desarrollo y mantenimiento de una comunidad epibentonica tropical. Tese de Doutorado, Universidad Central de Venezuela, Caracas.

BARROS, R., ROCHA, R.M. \& PIE, M. 2009. Human-mediated global dispersion of Styela plicata (Tunicata, Ascidiacea). Aquat. Invas. 4(1):45-57.

BERMUDEZ, I.R. \& JIMENEZ, G. 1975. Estudio comparativo de cuatro especies de ascidias de la Bahía de Mochima, Estado Sucre. Lagena (35-36):31-49.

BERRILL, N.J. 1932. Ascidians of the Bermudas. Biol. Bull. 62(1):77-88.

BigAtTI, G., MILOSLAVICH, P. \& PENCHASZADEH, P. 2005. Sexual differentiation and size at first maturity of the invasive mussel Perna viridis (Linnaeus, 1758) (Mollusca: Mytilidae) at La Restinga Lagoon (Margarita Island, Venezuela). Am. Malac. Bull. 20(1):65-69.

BUitrago, E., BUitrago, J., FREITES, L. \& LODEIROS, C. 2009. Identificación de factores que afectan el crecimiento y la supervivencia de la ostra de mangle, Crassostrea rhizophorae (Guilding, 1828), bajo condiciones de cultivo suspendido en la laguna de La Restinga, Isla de Margarita, Venezuela. Zoot. Trop. 27(1):79-90.

BOLAÑOS, J., CUESTA, J., HERNÁNDEZ, G., HERNÁNDEZ, J. \& FELDER, D. 2004. Abbreviated larval development of Tunicotheres moseri (Rathbun, 1918) (Decapoda: Pinnotheridae), a rare case of parental care among brachyuran crabs. Sci. Mar. 63(3):373-384.

CABRERA, T. \& PENOTH, E. 1988. Estudio de las condiciones físico-químicas de la Laguna de La Restinga, Isla de Margarita, Venezuela. Saber 1(2):23-37.

CARVER, C.E., CHISHOLM, A. \& MALLET, A.L. 2003. Strategies to mitigate the impact of Ciona intestinalis (L.) biofouling on shellfish production. J. Shellf. Res. 22(3):621-631.

CERVIGON, F. \& GOMEZ, A. 1986. Las lagunas litorales de la Isla de Margarita, sus recursos y conservación. Fundación Científica Los Roques, Caracas.

CONDE, J.E. \& CARMONA-SUÁREZ, C. 2003. Ecosistemas marino-costeros. In Biodiversidad en Venezuela (M. Aguilera, A. Azocar \& E. González Jiménez, eds). Fundación Polar, Caracas, p. 863-883. (v. II)

DARBYSON, E., LOCKE, A., HANSON, J.M. \& WILLISON, J.H.M. 2009. Marine boating habits and the potential for spread of invasive species in the Gulf of St. Lawrence. Aquat. Invas. 4(1):87-94.

DÍAZ, H., CONDE, J.E. \& ORIHUELA, B. 1992. Estimating the species number and cover of a mangrove-root community: a comparison of methods. Aust. J. Mar. Freshw. Res. 43(4):707-714.

DÍAZ, O. \& LIÑERO, M. 2009. Porcentaje del grado de infestación de Polypora cf. websteri Hartman, 1943 (Polychaeta: Spionidae) por clase de talla de Crassostrea rhizophorae (Guilding, 1828) de la laguna La Restinga (Isla de Margarita, Venezuela). Rev. Cient. 19(2):113-118.

FARNSWORTH. E.J. \& ELLISSON, A.M. 1996. Scale-dependent spatial and temporal variability in biogeography of mangrove root epibiont communities. Ecol. Monogr. 66(1):45-66.

FUENTES, L., SILVA, C. \& REYES, Y. 2003. Parásitos en juveniles de Lutjanus griseus (Pisces: Lutjanidae) de la Laguna de la Restinga Isla de Margarita, Venezuela. Interciencia 28(3):463-468.

GALÁN, A. 1976. Contribución al estudio de las incrustaciones biológicas en la laguna de La Restinga, Isla de Margarita, Venezuela. Bol. Inst. Oceanogr. Venez. 15(2):153-168

GLASBY, T.M., CONNELL, S.D., HOLLOWAY, M.G. \& HEWITT, C.L. 2007. Nonindigenous biota on artificial structures: could habitat creation facilitate biological invasions? Mar. Biol. 151(3):887-895.

GÓMEZ, A. 1981. Estudio de la comunidad de peces de dos localidades de la Laguna de La Restinga. Bol. Inst. Oceanog. Venez. 20(1-2):91-112.

GÓMEZ, A. 1983. Pigmentos clorofílicos, producción primaria y abundancia planctónica en el canal de entrada de la Laguna de La Restinga. Bol. Inst. Oceanog. Venez. 22(1-2):91-112.

GÓMEZ, A. 1991. Interacción entre un estuario negativo (Laguna de La Restinga, Isla de Margarita) y el mar Caribe adyacente. Bol. Inst. Oceanogr. Venez. 30(1-2):47-55.

GONZÁLEZ, A. 1976. Observaciones sobre la fijación larvaria de la ostra (Crassostrea rizophorae) en la laguna de La Restinga, Isla de Margarita (Venezuela). Lagena (37-38):13-14. 
GOODBODY, I. 1984a. The ascidian fauna of two contrasting lagoons in the Netherlands Antilles: Piscadera Baai, Curacao, and the Lac of Bonaire. Stud. Fauna Curaçao Caribb. Isl. 67(202):21-61.

GOODBODY, I. 1984b. Ascidians from Caribbean shallow water localities. Stud. Fauna Curaçao Caribb. Is1. 67(203):62-76.

GOODBODY, I. 1993. The ascidian fauna of a Jamaican lagoon: thirty years of change. Rev. Biol. Trop. 41(10):35-38.

GOODBODY, I. 1994. The tropical Western Atlantic Perophoridae (Ascidiacea): I. The genus Perophora. Bull. Mar. Sci. 55(1):176-92.

GOODBODY, I. 2000. Diversity and distribution of ascidians (Tunicata) in the Pelican Cays, Belize. Atoll Res. Bull. 480:302-326.

GOODBODY, I. 2003. The ascidian fauna of Port Royal, Jamaica. I. Harbor and mangrove dwelling species. Bull. Mar. Sci. 73(2):457-476.

GOODBODY, I. 2004. Diversity and distribution of ascidians (Tunicata) at Twin Cays, Belize. Atoll Res. Bull. 524:1-20.

GOODBODY, I. \& COLE, L. 1987. A new species of Perophora (Ascidiacea) from the Western Atlantic, including observations on muscle action in related species. Bull. Mar. Sci. 40(2):246-254.

GOODBODY, I. \& COLE, L. 2006. The tropical western Atlantic Perophoridae (Ascidiacea) ii. The genus Ecteinascidia. Bull. Mar. Sci. 79(1):49-70.

JOHNSON, L.E., RICCIARDI, A. \& CARLTON, J.T. 2001. Overland dispersal of aquatic invasive species: a risk assessment of transient recreational boating. Ecol. Applic. 11(6):1789-1799.

LAMBERT, G. 2005. Ecology and natural history of the protochordates. Can. J. Zool. 83(1):34-50.

LAMBERT, G. 2007. Invasive sea squirts: a growing global problem. J. Exp. Mar. Biol. Ecol. 342(1):3-4.

LEBLANC, N., DAVIDSON, J., TREMBLAY, R., MCNIVEN, M. \& LANDRY, T. 2007. The effect of anti-fouling treatments for the clubbed tunicate on the blue mussel, Mytilus edulis. Aquaculture 264(1-4):205-213.

LÓPEZ GRECO, L.S., BOLAÑOS, J., RODRÍGUEZ, E.M. \& HERNÁNDEZ, G. 2001. Survival and molting of the pea crab larvae Tunicotheres moseri Rathbun 1918 (Brachyura: Pinnotheridae) exposed to copper. Arch. Envir. Con. Tox. 40(4):505-510.

MARÍN, B., QUINTERO, A., BRUSSIÈRE \& DODSON, J. 2003. Reproduction and recruitment of white mullet (Mugil curema) to a tropical lagoon (Margarita Island, Venezuela) as revealed by otholith microstructure. Fish. Bull. 101(4):809-821.

MILLAR, R.H. 1953. On a collection of ascidians from the Gold Coast. Proc. Zool. Soc. London 123(2):277-325.

MILLAR, R.H. 1962. Some Ascidians from the Caribbean. Stud. Fauna Curaçao Caribb. Isl. 13(59):61-77.

MILLAR, R.H. 1978. Ascidians from the Guyana shelf. Neth. J. Sea Res. 12(1):99-106.

MILLAR, R.H. \& GOODBODY, I. 1974. New species of ascidians from the West Indies. Stud. Fauna Curaçao Caribb. Isl. 45(148):142-161.

MilOSLAVICH, P., PENSHASZADEH, P. \& BIGATTI, G. 2007. Imposex in gastropods from Venezuela. Cienc. Mar. 33(3):319-324.

MILOSLAVICH, P., KLEIN, E., MARTIN, A., BASTIDAS, C., MARIN, B. \& SPINIELLO, P. 2005. Marine biodiversity reviews: Venezuela. In Caribbean marine biodiversity: the known and the unknown (P. Miloslavich \& E. Klein, eds). Destech Publications, Lancaster.

MONNIOT, C. 1972a. Ascidies Stolidobranches des Bermudes. Bull. Mus. Natn. Hist. Nat. 43(57):617-643.

MONNIOT, C. 1972b. Ascidies Phlebobranches des Bermudes. Bull. Mus. Natn. Hist. Nat. 61(82):938-948.

MONNIOT, C. 1983a. Ascidies littorales de Guadeloupe II. Phlebobranches. Bull. Mus. Natn. Hist. Nat. 5(1):51-71.

MONNIOT, C. 1983b. Ascidies littorales de Guadeloupe. IV. Styelidae. Bull. Mus. Natn. Hist. Nat. 5(2):423-456.

MONNIOT, C. 1983c. Ascidies littorales de Guadeloupe VI. Pyuridae et Molgulidae. Bull. Mus. Natn. Hist. Nat. 5(4):1021-1044.

MONNIOT, C. \& MONNIOT, F. 1972. Clé mondial des genres d'ascidies. Arch. Zool. Exp. Gen. 113(3) :311-367.

MONNIOT, C. \& MONNIOT, F. 1984. Ascidies littorales de Guadeloupe. VII. Espèces nouvelles et complementaries a l'inventaire. Bull. Mus. Natn. Hist. Nat. 6(3):567-582.
MONNIOT, F. 1972. Ascidies aplousobranches des Bermudes. Polyclinidae et Polycitoridae. Bull. Mus. Hist. Nat. 61(82):949-962.

MONNIOT, F. 1983a. Ascidies littorales de Guadeloupe. I. Didemnidae. Bull. Mus. Hist. Nat. 5(1):5-49.

MONNIOT, F. 1983b. Ascidies littorales de Guadeloupe. III. Polyclinidae. Bull. Mus. Hist. Nat. 5(2):413-422.

MONNIOT, F. 1983c. Ascidies littorales de Guadeloupe V. Polycitoridae. Bull. Mus. Natn. Hist. Nat. 5(4):999-1019.

MONNIOT, F. 1984. Ascidies littorales de Guadeloupe VIII. Questions de systematique evolutive posées par les Didemnidae. Bull. Mus. Natn. Hist. Nat. 6(4):885-905.

MONTES, A.A. 1985. Aspectos bioecológicos de las poblaciones de ascidias solitarias en la Bahía de Mochima y costa sur del Golfo de Cariaco. Dissertação de Mestrado, Universidad de Oriente, Venezuela.

MONTES, A.A. \& PRIETO, A. 2005. Primer registro para Venezuela y aspectos morfológicos de la ascidia solitaria Styela barnharti Ritter \& Forsyth, 1917 (Tunicata: Stolidobranchia). Saber 17(1):81-83.

NIRCHIO, M., PÉREZ, J.E. \& CEQUEA, H. 1991. Allozyme variation of Lap Loci in Crassostrea rhizophorae in relation to temperature and/or salinity. Sci. Mar. 55(4):563-567.

ORIHUELA, B., DIAZ, H. \& CONDE, J.E. 1991. Mass mortality in a mangrove roots fouling community in a hypersaline tropical lagoon. Biotropica 23(4b):592-601.

PÉREZ, J.E., ALFONSO, C., SALAZAR, S.C., MACSOTAY, O., BARRIOS, J. \& MARTINEZ ESCARBASSIERE, R. 2007. Especies marinas exóticas y criptogénicas en las costas de Venezuela. Bol. Inst. Oceanogr. Venez. 46(1):79-96.

PETERSEN, J.K. 2007. Ascidian suspension feeding. J. Exp. Mar. Biol. Ecol. 342(1):127-137.

RAMÍREZ, P. 1996. Lagunas Costeras Venezolanas. Benavente \& Martínez, Porlamar.

ROCHA, R.M., FARIA, S.B. \& MORENO, T.R. 2005. Ascidians from Bocas del Toro, Panamá. I. Biodiversity. Caribb. J. Sci. 41(4):600-612.

ROCHA, R.M., KREMER, L.P., BAPTISTA, M.S. \& METRI, R. 2009. Bivalve cultures provide habitat for exotic tunicates in southern Brazil. Aquat. Invas. 4(1):195-205.

SALAZAR, J.C., ROSAS C., J.A., RODRÍGUEZ R., J.C. 2003. Condiciones sedimentológicas de la laguna La Restinga, Isla de Margarita, Venezuela. Interciencia 28(1):44-50.

SCELZO, M. 1972. Crecimiento y migración del camarón Penaeus brasiliensis Latreille (Decapoda. Penaeidae) en la Laguna de manglar de La Restinga, Isla de Margarita, Venezuela. Atlántica 5(2):107-108.

SLUITER, C.P. 1898. Tuniciers recueilli en 1896, par la Chazalie, dans la mer des Antilles. Mem. Soc. Zool. France 11:5-34.

SUTHERLAND, J.P. 1980. Dynamics of the epibenthic community on roots of the mangrove Rhizophora mangle, at Bahia de Buche, Venezuela. Mar. Biol. 58(1):75-84.

TOFFART, J.L. 1983. Les peuplements des racines de palétuviers en Guadeloupe (Antilles Françaises). I. Analyse floristique et faunistique; méthodologie et premier résultats. Bull. Ecol. 14(4):227-239.

Van der SLOOT, C.J. 1969. Ascidians of the family Styelidae from the Caribbean. Stud. Fauna Curaçao Caribb. Isl. 30(110):1-57.

Van NAME, W.G. 1945. The North and South American ascidians. Bull. Am. Mus. Nat. Hist. 84:1-476.

WASSON, K., ZABINC, C.J., BEDINGER, L., DIAZ, M.C. \& PEARSE, J.S. 2001. Biological invasions of estuaries without international shipping: the importance of intraregional transport. Biol. Conserv. 102(2):143-153.

YOUNG, C.M. \& CHIA, F.S. 1984. Microhabitat-associated variability in survival and growth of subtidal solitary ascidians during the first 21 days after settlement. Mar. Biol. 81(1):61-68.

ZANUI, A.H. 1990. Lista de ascidias cubanas. Poeyana 388:1-7.

ZOPPI DE ROA, E. 2003. Biodiversidad de Venezuela. In Biodiversidad en Venezuela (M. Aguilera, A. Azocar \& E. González Jiménez, eds). Fundación Polar, Caracas, p. 522-532. 